\title{
STRATEGI KOMUNIKASI ELITE LOKAL DAN UMAT HINDU DALAM PRAKTIK TABUH RAH PENGANGON PADA MASA PANDEMI COVID-19 DI DESA ADAT KAPAL KECAMATAN MENGWI KABUPATEN BADUNG
}

\author{
I Ida Bagus Surya Negara a,1 \\ Ida Bagus Gede Candrawan $\underline{a}$ \\ Made Redana a \\ a Universitas Hindu Negeri I Gusti Bagus Sugriwa Denpasar \\ 1 Corresponding Author, email: suryanegaraagustus92@gmail.com (Negara)
}

\section{ARTICLE INFO}

\section{Article history:}

Received: 14-07-2021

Revised:13-08-2021

Accepted: 11-09-2021

Published: 30-09-2021

\section{Keywords:}

Communication

strategy, Local

Elite, Covid-19

Pandemic

\section{ABSTRACT}

One of the traditions in Bali that is still preserved today is the Tabuh Rah Pengangon Tradition in Subak Tegan, Traditional Village of Kapal. This tradition is carried out once a year at harvest. In 2019 the world was shocked by the Covid19 virus. The development of the virus is quite massive and the increase in cases in Indonesia has resulted in the government taking preventive measures by implementing Large-Scale Social Restrictions (PSBB). With circulars from the Bali provincial government and PHDI, the role of local elites is important in conveying information to the public. This study focuses on discussing the essence and communication strategies used by local elites and Hindus as well as the religious system that took place during the Covid-19 Pandemic. This study uses a qualitative method with an empirical approach. Data collection was done by interview and observation techniques. The results show that the essence of communication used is ritual communication which is carried out as a form of habitual behavior. The communication strategy between local elites and Hindus is divided into 3 stages, namely the planning stage by holding sangkep, the preparation stage by distributing notification letters by kesinoman and the implementation stage of the local elite overseeing the event. During the pandemic, the Tabuh Rah Pengangon tradition process continues, it's just that the implementation is now limited to 25 people, the venue is reduced and the health protocol is still implemented

\section{PENDAHULUAN}

Pulau Bali dikenal sebagai tujuan destinasi wisata dunia mulai dari alam, budaya, dan tradisinya. Ditinjau dari kependudukan, mayoritas penduduk Bali beragama Hindu. Secara umum tradisi di Bali dapat dikelompokan menjadi 4 (empat) kelompok tradisi, yaitu Tradisi keagamaan atau ibadah meliputi Mesegeh, Mebanten, Mebakti, Upacara Panca
Yadnya, termasuk Dana Punia. Banyaknya pengaruh budaya asing yang masuk ke Bali tidak semata- mata mempengaruhi budaya asli Bali. Hal ini terjadi karena masyarakat Hindu Bali memiliki iman dan kepercayaan akan ajaran agama Hindu sehingga dapat menyaring budayabudaya asing tersebut dengan baik. Menurut Mantra (1996: 8), Bali mempunyai landasan kokoh yang tidak mudah tergoncangkan oleh 
budaya populer dari luar yang tidak serasi dengan budaya dirinya.

Salah satu tradisi di Bali yang masih dilestarikan hingga saat ini adalah Tradisi Tabuh Rah Pengangon. Tradisi ini dapat dijumpai di daerah Kabupaten Badung yaitu di Subak Tegan Desa Adat Kapal. Tradisi ini diadakan di tiga tempat yang berbeda, yaitu di Pura Uluncarik, Pura Bedugul dan di depan Pura Bale Agung. Tradisi Tabuh Rah Pengangon diselenggarakan setiap satu tahun sekali, tepatnya saat panen masa (usia padi sekitar 105 hari). Masyarakat Subak Tegan di Desa Adat Kapal melaksanakan tradisi ini memiliki tujuan memohon kesuburan dan keselamatan khususnya untuk tanaman padi kehadapan Ida Sang Hyang Widhi Wasa, dalam manifestasi beliau sebagai Dewi Sri.

Seiring berjalannya waktu pelaksanaan Tabuh Rah Pengangon mengalami beberapa perubahan, terutama ketika Indonesia mengalami pandemi Covid-19. Pada tahun 2019 dunia dihebohkan dengan adanya wabah penyakit virus Covid-19 atau yang disebut coronavirus. Coronavirus adalah sekumpulan virus dari subfamili orthocoronavirinae dalam keluarga coronaviridae dan ordo nidovirales. Virus ini yang dapat terjangkit pada burung dan mamalia, termasuk manusia. Pada manusia coronavirus menyebabkan infeksi saluran pernapasan yang umumnya ringan, seperti pilek.

Virus ini berasal dari kota Wuhan Tiongkok di pasar hewan dan makanan laut di Kota Wuhan. Penyebaran virus ini dapat ditularkan melalui udara dan manusia (WHO, 2021). Pada tahun 2020, penularan virus ini semakin berkembang dan cukup masif hingga mendunia.

Lebih jauh, adanya peningkatan kasus Covid-19 di Indonesia mengakibatkan pemerintah melakukan upaya pencegahan lebih masif dengan menerapkan Pembatasan Sosial Berskala Besar (PSBB) demi memutus mata rantai penyebaran virus corona. Menindaklanjuti langkah PSBB yang dilakukan oleh pemerintah, Gubernur Bali I Wayan Koster mengeluarkan surat instruksi Nomor 267/01-B/HK/2020 yang mengatakan upacara Melasti, Makiyis, Melis, Tawur Kesanga dan Pangrupukan dan tradisi yang yang harus dilaksanakan dengan melibatkan para petugas pelaksana upacara dalam jumlah yang sangat terbatas, paling banyak 25 orang hanya untuk pelaksana utama, yaitu: pemangku, sarati dan pembawa sarana utama di masa pandemic.

Dikaitkan dengan tradisi Tabuh Rah Pengangon yang ada di Desa Adat Kapal, adanya surat edaran dari pemerintah provinsi Bali dan PHDI maka peranan elite lokal khususnya di Desa Adat Kapal menjadi sosok penting dalam masyarakat karena mereka dapat diposisikan sebagai opinion leader. Keberadaan elite lokal menjadi penting dalam pelaksanaan tradisi ini karena memiliki kedekatan dengan masyarakat secara interpersonal, sehingga diharapkan para elite lokal dapat meneruskan informasi dan bentuk komunikasi yang dilakukan oleh elit lokal tersebut mendapat perhatian khusus oleh masyarakatnya.

Peran dari elite lokal di Desa Adat Kapal sangat berpengaruh terhadap tradisi Tabuh Rah Pengangon, terutama dalam menyampaikan informasi kepada masyarakat terkait dengan adanya batasan kapasitas yang dianjurkan pemerintah dan tetap melaksanakan protokol kesehatan kepada warga Desa Adat Kapal selama upacara berlangsung.

Tak jarang perbedaan dalam memahami suatu informasi menjadi sebuah tantangan yang ditemui oleh elite lokal dalam penyampaian informasi kepada masyarakat. Perbedaan dalam pemahaman masyarakat tersebut dapat menghambat terlaksananya upacara, sehingga strategi komunikasi yang tepat penting untuk dirancang dan dimiliki oleh elite lokal sehingga dapat meminimalisir terjadinya kesalahpahaman.

Berdasarkan fenomena tersebut maka peneliti tertarik untuk mengungkapkan tradisi Tabuh Rah Pengangon di masa Covid-19 kedalam bentuk tulisan yang berjudul Strategi Komunikasi Elite lokal dan Umat Hindu dalam Tradisi Tabuh Rah Pengangon pada Masa Covid19 di Desa Adat Kapal Kecamatan Mengwi Kabupaten Badung

\section{METODE PENELITIAN}

Metode penelitian merupakan langkah yang dilakukan oleh peneliti untuk mengumpulkan informasi atau data dengan melakukan investigasi dan penelitian lebih 
lanjut pada data yang telah didapatkan tersebut. Dalam penelitian Strategi Komunikasi Elite lokal dan Umat Hindu Dalam Praktik Tabuh Rah Pengangon Pada Masa Covid-19 di Desa Adat Kapal Kecamatan Mengwi Kabupaten Badung peneliti menggunakan metode Kualitatif.

Pendekatan yang digunakan dalam penelitian ini adalah pendekatan empiris, dimana masalah yang diteliti atau diselidiki telah ada dalam kenyataannya. Lokasi penelitian dilakukan di Desa Adat Kapal Kecamatan Mengwi Kabupaten Badung karena sebagai desa yang mayoritasnya penduduknya beragama Hindu sampai saat ini masih kental dengan tradisi yang dilakukan secara turun temurun.

Teknik pengambilan data dilakukan menggunakan metode observasi dan wawancara. Observasi dilakukan dalam penelitian ini mencakup observasi partisipasi dan non partisipasi yang bersifat insidental. Penggunaan teknik pengumpulan data ini dimaksudkan untuk dapat mengamati apa yang dikerjakan, dengarkan dan apa yang mereka katakan dan berpartisipasi dalam aktivitas kewangsaan dalam konteks memahami proses-proses perubahan masyarakat dan budaya terutama dari segi tindakan- tindakan sosial yang tampak nyata dilakukan partisipan penelitianAdapun aspek yang di observasi dalam penelitian ini adalah bagaimana interaksi elit lokal yang ada di Desa Adat Kapal dalam menyampaikan informasi kepada masryarakat baik itu saat perencanaan, persiapan, pelaksanaan hingga pasca pelaksanaan tradisi Tabuh Rah Pengangon.

Wawancara

dilakukan baik secara terstruktur maupun mendalam (in-depth Interview), kepada key informan yang sudah teridentifikasi melalui pendekatan posisional dalam struktur desa pakraman, reputasional, kompetensi dan pemahamannya terhadap persoalan yang diteliti. Wawancara dipergunakan untuk mengetahui tentang secara mendalam mengenai strategi komunikasi elite lokal pada masa pandemi Covid-19 dan umat hindu dalam tradisi Tabuh Rah Pengangon yang dilaksanakan oleh umat itu pada lokasi penelitian

\section{HASIL DAN PEMBAHASAN}

\section{Esensi Komunikasi yang Terjalin pada Elite Lokal dan Umat Hindu dalam Praktik Religi}

Berdasarkan hasil dari observasi dan wawancara yang dilakukan kepada sepuluh orang sebagai elite lokal dan umat Hindu di Desa Adat Kapal, secara gambaran umum jumlah penduduk Desa Adat Kapal pada tahun anggaran 2020 adalah 11.718 jiwa, terdiri dari laki-laki 5.816 jiwa, Perempuan 5.902 jiwa, dengan jumlah Kepala Keluarga (KK) 2.525 jiwa. Desa Adat Kapal secara administrasi, kelurahan Kapal termasuk dalam wilayah Kecamatan Mengwi, Kabupaten Badung, Provinsi Bali. Jarak dari pusat pemerintahan yaitu $5 \mathrm{~km}$, jarak dari ibu kota Kabupaten Badung kurang lebih 4 km, jarak dari kota Provinsi Bali sekitar $17 \mathrm{~km}$.

Kelurahan Kapal terdiri dari 16 lingkungan yaitu : (1) Lingkungan Panglan, (2) Lingkungan Uma, (3) Lingkungan Cempaka, (4) Lingkungan Celuk, (5) Lingkungan Basang Tamiang, (6) lingkungan Titih, (7) Lingkungan Pemebetan, (8) Lingkungan Langon, (9) Lingkungan Peken Delodan, (10) Lingkungan Peken Baleran, (11) Lingkungan Ganggasari, (12) Lingkungan Tambak Sari, (13) Lingkungan Muncan, (14) Lingkungan Tegalsaat, (15) Lingkungan Belulang dan (16) Lingkungan Gegadon.

Jika dilihat dari aspek adat, Kelurahan Kapal terdiri dari 18 banjar yakni : (1) Banjar Panglan Baleran, (2) Banjar Panglan Delodan, (3) Banjar Uma, (4) Banjar Cempaka, (5) Banjar Celuk, (6) Banjar Basangtamiang, (7) Banjar Titih, (8) Banjar Pemebetan, (9) Banjar Peken Delodan, (10) Banjar Peken Baleran, (11) Banjar Ganggasari, (12) Banjar Langon, (13) Banjar Tambaksari, (14) Banjar Muncan, (15) Banjar Tegalsaat Baleran, (16) Banjar Tegalsaat Delodan, (17) Banjar Belulang dan (18) Banjar Gegadon.

Desa Adat Kapal dipimpin oleh Bendesa Adat. Di Desa Adat Kapal, pengangkatan seorang pemimpin di wilayah Desa Adat adalah berdasarkan pemilihan yang dilakukan oleh krama ngarep (warga yang ngayah Banjar) khususnya para warga laki-laki melalui rapat (paruman) di masing-masing Banjar. Setelah penetapan seorang sebagai seorang pemimpin barulah dilaksanakan upacara pengesahan secara niskala, bahwa mereka berhak untuk 
memerintah krama desa dalam kewajibannya melaksanakan upacara panca yadnya dan menjalankan adat istiadat di desanya

Memperhatikan susunan pengurus bendesa Adat Kapal ada 18 orang pengurus bendesa diantaranya kepala desa, wakil kepala desa, skeretaris desa, bendahara desa dan kesinoman atau penyampai informasi kepada masyarakat. Dilihat dari karasteristik agama, maka masyarakat Desa Adat Kapal tidak 100\% memeluk agama Hindu.

Dilihat dari esensi komunikasi yang terjalin pada elite lokal dan umat Hindu dalam praktik religi, khususnya dalam pelaksanaan Tradisi Tabuh Rah Pengangon di Desa Adat Kapal, esensi komunikasi tradisional yang terjalin yaitu berupa sangkep. Sangkep biasanya dihadiri oleh seluruh warga desa setempat. Perbedaan yang terjadi sangkep selama pandemic Covid-19 di Desa Adat Kapal terletak pada pelaksanaan sangkep dan jumlah orang yang menghadiri acara sangkep. Pelaksanaan sangkep dilaksanakan di bale banjar Desa Adat Kapal dengan dihadiri oleh elit lokal dan beberapa warga setempat.

Menurut bendesa Adat Kapal menyatakan bahwa pengertian Tabuh Rah Pengangon merupakan suatu ungkapan rasa syukur masyarakat subak khususnya subak Tegan kepada Ida Sang Hyang Widhi Wasa karena sudah memberikan keselamatan dan panen yang berlimpah. Ungkapan rasa syukur ini direpresentasikan dalam bentuk tradisi dengan melaksanakan upacara dan sarana pokoknya menggunakan ketupat dan bantal. Ketupat dan bantal ini akan digunakan oleh krama subak untuk sabung perang (metetimpugan) sesama krama subak yang nantinya di bagi menjadi 2 kelompok dan dilaksanakan di depan pura Bale Agung.

Tabuh Rah Pengangon merupakan upacara yang diperingati untuk persembahan kehadapan Ida Sang Hyang Widhi Wasa (Dewi Sri) karena sudah dilimpahkan panen yang baik dan akan memberikan kesuburan kepada masyarakat khususnya masyarakat Desa Adat Kapal. Tradisi ini sangat unik dapat dilihat dari sarana yang digunakan. Ketupat dan bantal ini dipercayai sebagai simbul purusa dan pradhana perlambang kesuburan.
Dalam pelaksanaannya, ketupat dan bantal bersama-sama dilempar- lempar oleh dua kelompok yang menjadi pelaku dalam pelaksanaan tradisi Tabuh Rah Pengangon. Setelah pelaksanaan tradisi ini berakhir, ketupat dan bantal yang telah digunakan lalu dipungut dan dibawa pulang oleh karma atau masyarakat sekitar untuk diberikan kepada hewan ternak, yang dimana dalam hal ini adalah babi dan itik yang dipelihara oleh warga.

Lebih jauh, Tradisi Tabuh Rah Pengangon ini diadakan di tiga tempat yang berbeda, yaitu di Pura Uluncarik, Pura Bedugul dan di depan Pura Bale Agung. Pelaksanaan pertama diselenggarakan di Pura Uluncarik dengan menghaturkan piodalan alit. Pelaksanaan yang kedua di Pura Bedugul dengan menghaturkan banten perani berupa ketupat dan bantal dan pelaksanaan yang ketiga dilaksanakan di depan Pura Bale Agung yang merupakan menjadi tempat pokok dari pelaksanaan tradisi Tabuh Rah Pengangon.

Dalam pelaksanaannya selama masa pandemic Covid-19, tradisi Tabuh Rah Pengangon dipimpin oleh bendesa adat Desa Adat Kapal. Pemimpin upacara dalam tradisi ini memiliki peranan penting dalam upacara ini, baik dari tahap perencanaan, persiapan hingga pelaksanaan. Waktu pelaksanaan upacara kali ini tetap dilakukan pada Purnama Kapat yang sesuai dengan penanggalan kalender Bali.

Adapun sarana yang perlu dipersiapkan adalah berupa banten yang terdiri dari Peras Daksina, Banten Rayunan, Rayunan, Banten Dapetan Tumpeng Pitu, Banten Sorohan, Penyeneng, Pengeresikan, Tabuh Tuak, Segehan Cacahan, dan Banten Pepranian. Banten ini dipersiapkan di rumah umat Hindu yang biasanya menjadi Pengayah pura di Desa Adat Kapal. Persiapan ini tetap menjalankan protokol kesehatan.

Persiapan tidak hanya sarana yang dibutuhkan, tetapi juga tempat pelaksanaan upacara Tabuh Rah Pengangon. Sebelum pandemic, pelaksanaan Tabuh Rah Pengangon diadakan di 3 tempat yaitu di Pura Uluncarik, Pura Bedugul dan Pura Bale Agung, namun karena pandemi pelaksanaan dilaksanakan di dua tempat saja untuk menghindari kerumunan. Selain banten yang disiapkan, hal-hal yang 
dibutuhkan sebagai protokol kesehatan juga dipersiapkan, seperti thermogun, tempat cuci tangan hingga handsanitizer. Tahap selanjutnya adalah pelaksanaan upacara Tabuh Rah

Esensi komunikasi adalah aktivitas penyampaian dan penerimaan suatu pesan. Komunikasi menjadi cara untuk memenuhi kebutuhan dan tujuan manusia dalam berbagai aspek kehidupan. Komunikasi membuat manusia mampu untuk melakukan kerjasama, namun komunikasi juga memungkinkan terjadinya konflik.

Esensi komunikasi yang digunakan oleh elite lokal dan umat Hindu di Desa Adat Kapal dalam praktik religi adalah komunikasi ritual. Komunikasi ritual adalah sebuah fungsi komunikasi untuk memenuhi jati diri manusia sebagai individu, anggota komunitas sosial, dan menjadi salah satu unsur dari alam semesta. Di dalam individu yang melakukan komunikasi ritual menegaskan komitmennya kepada tradisi keluarga, suku, bangsa, ideologi, atau agamanya.

Ritual yang dijalankan masyarakat Desa Adat Kapal adalah bentuk komunikasi tradisional yang mempunyai fungsi sebagai bentuk-bentuk dari perilaku yang menjadi sebuah kebiasaan. Dalam pelaksanaan Tradisi Tabuh Rah Pengangon di Desa Adat Kapal, esensi komunikasi tradisional yang terjalin yaitu berupa sangkep. Sangkep adalah suatu bentuk kegiatan yang biasanya dihadiri oleh warga dalam suatu wilayah berkumpul dan saling membahas masalah secara bersama-sama dan menemukan solusi dari suatu permasalahan sehingga menghasilkan keputusan yang bertujuan untuk mencapai mufakat dengan mementingkan kepentingan bersama. Sangkep biasanya dihadiri oleh seluruh

Pengangon. Pada tahap ini, para elit local dan umat hindu yang menjadi perwakilan desa mengikuti pelaksanaan dengan tetap menjalankan protocol kesehatan warga desa setempat. Perbedaan yang terjadi sangkep selama pandemic Covid-19 di Desa Adat Kapal terletak pada pelaksanaan sangkep dan jumlah orang yang menghadiri acara sangkep. Pelaksanaan sangkep dilaksanakan di bale banjar Desa Adat Kapal dengan dihadiri oleh elit local dan beberapa warga setempat.
Tradisi Tabuh Rah Pengangon dilaksanakan sebagai ungkapan rasa syukur kehadapan Ida Sang Hyang Widhi Wasa atas hasil panen yang berlimpah. Selain percaya dengan Ida Sang Hyang Widhi Wasa, masyarakat atau krama di subak Tegan Desa Adat Kapal juga memperhatikan yang dinamakan Drsta. Drsta dalam bahasa Sansekerta berasal dari kata drs artinya melihat atau memandang. Kemudian menjadi kata Drsta berarti pandangan. Drsta terdiri atas beberapa macam yaitu; Sastra Drsta, Desa drsta, Loka Drsta, Kuna drsta atau Purwa drsta dan Kuna drsta.

Krama subak Tegan Desa Adat Tegan juga berpedoman dengan Sastra drsta yaitu suatu tradisi agama Hindu yang bersumber pada pada pustaka-pustaka suci. Sumber utama yang dimaksud adalah pustaka suci Veda. Pokokpokok ajaran Veda kemudian memberi jiwa dan nafas pada pustaka-pustaka suci agama Hindu berikutnya. Di Bali ajaran agama Hindu itu ditulis dalam Lontar yaitu daun pohon tal dengan huruf Bali (Sukrawati dkk, 2006 :8- 9).

Menurut Koentjaraningrat (dalam Pratiwi, 2017) terdapat lima komponen sistem religi, yaitu emosi keagamaan, umat beragama, sistem keyakinan, sistem ritus dan upacara dan peralatan ritus dan upacara. Dikaitkan dengan Tradisi Tabuh Rah Pengangon yang dilakukan di Desa Adat Kapal, emosi keagamaan yang muncul karena adanya peristiwa musim paceklik di Desa Kapal dan mengakibatkan kekacauan di masyarakat tersebut. Adapun umat beragama yang dimaksudkan disini adalah seluruh masyarakat atau warga di Desa Adat Kapal yang menjalankan tradisi tersebut setiap tahunnya.

Dilihat dari sistem keyakinannya, tradisi ini meyakini bahwa upacara ini sebagai bentuk rasa syukur masyarakat subak khususnya subak Tegan kepada Ida Sang Hyang Widhi Wasa karena sudah memberikan keselamatan dan panen yang berlimpah. Terkait dengan system dan peralatan upacara di masa pandemic Covid19 terdapat beberapa hal yang mengalami improvisasi, seperti adanya pembatasan jumlah orang dalam mengikuti proses upacara, menjalankan protocol kesehatan dengan ketat, koordinasi dengan satgas Covid19, pelaksanaan berlangsung hanya di Pura Ulun 
Carik dan Pura Bedugul. Menurut Middleton strategi komunikasi adalah kombinasi terbaik dari semua elemen komunikasi mulai dari komunikator, pesan, saluran (media) penerima sampai pada pengaruh (efek) yang dirancang untuk mencapai tujuan komunikasi yang optimal.

\section{Strategi Komunikasi Elite Lokal dan Umat Hindu dalam Praktik Tabuh Rah Pengangon pada Masa Pandemi Covid-19}

Dalam komunikasi, seorang elite lokal di setiap daerah harus mampu mempengaruhi warga untuk memaksimalkan supaya tidak adanya konflik intern antar umat Hindu. Sistem komunikasi yang baik untuk memberikan arahan bagi warga umat Hindu di Desa Adat Kapal tentang bahaya dari virus Covid-19 ini agar warga umat Hindu di Desa Adat Kapal tetap menerapkan anjuran pemerintah dengan menerapkan protokol kesehatan.

Tujuan strategi komunikasi, tidak terlepas dari pola komunikasi elite lokal dalam menjalankan tugasnya. Hal ini dibutuhkan adanya komunikasi elite lokal dan umat Hindu yang baik dalam menjalankan surat edaran gubernur Bali agar umat Hindu mau menjalankan tradisi yang dibatasi tanpa mengurangi makna. Tanpa adanya komunikasi yang baik antara elite lokal dan umat Hindu di Desa Adat Kapal, Seorang pemimpin instansi dalam menjalankan kepemimpinannya tentu memiliki pengalaman, maka seorang pemimpin dituntut harus mampu menggunakan kemampuan yang dimilikinya agar pesan yang disampaikan diterima dan komunikasi berjalan efektif. Dari pemaparan diatas strategi yang di pakai pisau pembedah strategi elite lokal dan umat Hindu adalah komunikasi Instrumental.

Mulyana (2012: 5-33), komunikasi instrumental memiliki beberapa tujuan umum yakni menginformasikan, mengajar, mendorong, mengubah sikap dan keyakinan, dan mengubah perilaku atau menggerakkan tindakan, dan juga menghibur. Adapun inti dari tujuan tersebut adalah membujuk (bersifat persuasif) kepada lawan bicara. Komunikasi yang mengandung muatan persuasif dalam arti bahwa pembicara menginginkan pendengarnya mempercayai bahwa fakta atau informasi yang disampaikannya akurat dan layak diketahui.

Hubungan elite lokal dengan umat Hindu sangat berperan dalam menjalankan sebuah upacara adat maupun tradisi yang tertuang dalam estetika. Elite lokal sebagai tumbak kepeminpinan dalam menjalankan roda pemrintahan yang menganut dalam sistem tradisi religi yang bisa mendorong masyarakatnya untuk menjaga keharmonisan. Elite lokal sebagai komunikator untuk menyampaikan beberapa hal dalam situasi Covid-19. Meskipun situasi pandemi saat ini tradisi upacara Tabuh Rah Penganggon tetap dilaksankan tanpa menghilangkan makna dan estetika yang terkandung di dalam lontar.

Dalam hal ini elite lokal mengajak umat Hindu di Desa Adat Kapal melakukan peranannya dengan strategi komunikasi instrumental. Maksud dan tujuan strategi ini sebagai pesan edukasi serta merangkul masyarakat guna pesan yang disampaikan akurat dan tepat pada masyarakat umat Hindu dalam segala situasi dan kondisi. Elite lokal membuat rancangan manajerial dalam menangani situasi yang mampu membujuk masyarakat agar taat dan mau menjalankan anjuran pemerintah. Pesan keputusan disampaikan elite lokal tidak semata-mata menggunakan insan pribadi namun mengutamakan kepentingan umum khususnya umat Hindu agar tidak terjadi kesalahpahaman antara pimpinan dengan bawahannya. Elite lokal dan umat Hindu sebagai penunjang dalam instruksi anjuran pemerintah sebagai hubungan komunikasi dari atas-ke bawah yang disebut komunikasi vertical. Maksud komunikasi vertical ini antara lain elite lokal dengan umat Hindu di Desa Adat Kapal.

Di Desa Adat Kapal mempunyai tradisi Tabuh Rah Penganggon yang dilaksanakan setiap setahun sekali yang jatuh pada Purnama Sasih Kapat. Masyarakat dalam Kegiatan upacara Tabuh Rah Pengganggon pada umumnya dilaksanakan menggunakan banyak orang, tetapi karena situasi pandemi orang terlibat didalamnya hanya dibatasi beberapa orang (maksimal 25 orang).

Strategi komunikasi merupakan rencana dan teknik dalam rangkaian aktifitas komunikasi 
untuk mencapai suatu tujuan. Tujuan dalam strategi komunikasi adalah agar informasi yang disampaikan oleh komunikator dapat tersampaikan kepada komunikan sehingga dapat mencegah terjadinya konflik. Strategi komunikasi ini penting untuk dipersiapkan, terutama untuk para leader maupun elite lokal dalam memberikan informasi kepada masyarakat sehingga dapat mencegah terjadinya konflik di kemudian hari.

Adapun strategi yang dijalankan oleh elite lokal yang berada di Desa Adat Kapal ketika melakukan perencanaan ritual Tabuh Rah Pengangon adalah dengan melakukan rapat atau sering disebut dengan sangkep. Sangkep dilakukan untuk membahas terkait dengan menentukan hari baik atau sering disebut dengan dewasa. Penentuan hari baik sebelum menyelenggarakan suatu upacara di Bali sangatlah krusial. Hal ini menjadi penentu lancar atau tidaknya suatu kegiatan yang kita laksanakan.

Selain membahas tentang hari baik, dalam sangkep para elite lokal dan umat Hindu membicarakan tentang tempat pelaksanaan dan apa saja yang diperlukan selama persiapan hingga pasca upacara. Mengingat upacara ini akan dilaksanakan selama pandemi, maka para elite lokal dan umat Hindu melakukan koordinasi dengan Satgas Covid-19 sehingga pelaksanaan upacara tidak melenceng dari surat edaran nomor 267/01-B/HK/2020. Setelah ada musyawarah mufakat, hasil sangkep tadi lalu di buat dalam bentuk surat edaran kepada masyarakat sebagai permakluman karena ada perubahan dalam pelaksanaan upacara di masa pandemi.

Setelah tahap perencanaan, tahap selanjutnya adalah melakukan persiapan upacara Tabuh Rah Pengangon. Tahap ini para elite lokal, pemangku beserta beberapa umat Hindu melakukan persiapan sarana dan prasarana yang diperlukan untuk upacara. Adapun sarana yang perlu dipersiapkan adalah berupa banten yang terdiri dari Peras Daksina, Banten Rayunan, Rayunan, Banten Dapetan Tumpeng Pitu, Banten Sorohan, Penyeneng, Pengeresikan, Tabuh Tuak, Segehan Cacahan, dan Banten Pepranian. Banten ini dipersiapkan di rumah umat Hindu yang biasanya menjadi
Pengayah pura di Desa Adat Kapal. Persiapan ini tetap menjalankan protokol kesehatan.

Persiapan tidak hanya sarana yang dibutuhkan, tetapi juga tempat pelaksanaan upacara Tabuh Rah Pengangon. Sebelum pandemic, pelaksanaan Tabuh Rah Pengangon diadakan di 3 tempat yaitu di Pura Uluncarik, Pura Bedugul dan Pura Bale Agung, namun karena pandemi pelaksanaan dilaksanakan di dua tempat saja untuk menghindari kerumunan. Selain banten yang disiapkan, hal-hal yang dibutuhkan sebagai protokol kesehatan juga dipersiapkan, seperti thermogun, tempat cuci tangan hingga handsanitizer.

Lebih lanjut, pada tahap ini para kesinoman juga mengedarkan surat edaran yang telah dibuat saat tahap perencanaan. Surat edaran ini berisi permakluman pelaksanaan dengan mematuhi protokol kesehatan yang dianjurkan pemerintah. Surat edaran ini sebagai bentuk strategi komunikasi yang dilakukan oleh elite lokal di Desa Adat Kapal agar umat Hindu dapat paham dan memaklumi kondisi yang ada. Tahap selanjutnya adalah pelaksanaan upacara Tabuh Rah Pengangon. Pada tahap ini, para elit local dan umat hindu yang menjadi perwakilan desa mengikuti pelaksanaan dengan tetap menjalankan protocol kesehatan. Peran elite lokal disini sangat penting dalam menyampaikan informasi ataupun pesan kepada para umat Hindu yang hadir. Ketika ada umat Hindu yang tidak menjalankan protocol dengan benar, para elite lokal yang bergerak dan menegur para umat Hindu sehingga pelaksanaan upacara Tabuh Rah Pengangon dapat berjalan dengan baik dan lancar.

Tidak hanya dengan menegur bagi umat Hindu, para elite lokal juga menjadi panutan bagi umat Hindu dalam menjalankan protocol kesehatan dengan benar. Strategi yang dilakukan para elite lokal adalah dengan menjalankan protocol kesehatan dengan benar sehingga dapat menjadi contoh bagi para umat Hindu lainnya. Hal ini secara tidak langsung menjadi satu cara mengisyaratkan dan menyampaikan komunikasi non-verbal kepada umat Hindu di Desa Adat Kapal selama proses upacara berlangsung. 


\section{SIMPULAN}

Berdasarkan hasil penelitian maka dapat ditarik kesimpulan sebagai berikut:

1. Esensi komunikasi merupakan suatu proses dalam penyampaian dan penerimaan suatu pesan. Esensi komunikasi yang digunakan oleh elite lokal dan umat Hindu di Desa Adat Kapal dalam praktik religi adalah komunikasi ritual. Komunikasi ritual memiliki fungsi untuk pemenuhan jati diri manusia sebagai individu, sebagai anggota komunitas sosial, dan sebagai salah satu unsur dari alam semesta. Dalam melakukan komunikasi ritual, individu menegaskan komitmennya kepada tradisi keluarga, suku, bangsa, ideologi, atau agamanya. Ritual yang dijalankan masyarakat Desa Adat Kapal adalah bentuk komunikasi tradisional yang mempunyai fungsi sebagai bentuk-bentuk dari perilaku yang bersifat kebiasaan.

2. Di masa pandemi ini proses tradisi Tabuh Rah Pengangon tetap berjalan tanpa mengurangi makna hanya saja pelaksanaannya kini dibatasi 25 orang, dengan tetap melaksanakan protokol kesehatan. Peran elite lokal sebagai komunikator untuk menyampaikan beberapa hal dalam situasi Covid-19, sebagai komunikator surat edaran guburnur tentang pelaksanaan tradisi di Bali yang jumlahnya tidak boleh lebih dari 25 orang, elite lokal sebagai komunikator kepada umat Hindu bahayanya virus Covid-19, dan elite lokal sebagai komunikator agar warga di Desa Adat Kapal tetap melaksanakan protokol kesehatan.

3. Strategi komunikasi yang dibangun antara elite lokal dan umat Hindu di Desa Adat Kapal dalam tradisi Tabuh Rah Pengangon dibagi menjadi 3 tahap, tahap perencanaan strategi komunikasi yang dibangun adalah dengan melakukan sangkep membahas mengenai penentuan hari baik, koordinasi dengan Satgas Covid-19, merencanakan hal-hal apa saja yang dibutuhkan upacara serta membuat surat edaran permakluman. Tahap berikutnya adalah persiapan, dimana strategi komunikasi yang dibangun adalah dengan mengedarkan surat edaran yang telah dibuat saat tahap perencanaan oleh para kesinoman. Pada tahap pelaksanaan, ketika ada umat Hindu yang tidak menjalankan protocol dengan benar, para elite lokallah yang bergerak dan menegur para umat Hindu sehingga pelaksanaan upacara Tabuh Rah Pengangon dapat berjalan dengan baik dan lancar. Strategi komunikasi lain yang dilakukan para elite lokal adalah dengan menjalankan protocol kesehatan dengan benar sehingga dapat menjadi contoh bagi para umat Hindu lainnya.

\section{Saran}

Berdasarkan kesimpulan diatas dapat menyampaikan beberapa saran yang dapat dijadikan bahan pertimbangan antara lain:

1. Bagi Warga Umat Hindu di Desa Adat Kapal Bagi seluruh umat Hindu di Desa Adat

Kapal yang terkena imbas dari Covid-19 seperti pekerja pariwisata, pengusaha, dan anakanak yang belajar secara daring diharapkan tetap semangat, bersabar dan berdoa. Karena Covid-19 adalah virus yang mematikan agar terhindar hendaknya ikuti aturan pemerintah dengan melaksanakan protokol kesehatan. Supaya orang yang kita cintai tidak terkena dari ganasnya Covid-19. Tuhan selalu memberikan cobaan kepada umatnya di balik cobaan ini ada hikmah yang dapat kita petik.

2. Bagi Elite Lokal Di Desa Adat Kapal Bagi elite lokal untuk meningkatkan kinerja di masa pandemi Covid-19 dengan melakukan komunikasi secara langsung kepada warga di Desa Adat Kapal agar warga tetap melaksanakan anjuran pemerintah dengan menerapkan protokol kesehatan. Pentingnya peran dari peminpin dan warga Desa Adat Kapal melakukan koordinasi apabila ada keluarga atau kerabat yang terkena Covid-19 agar melapor ke satgas penanganan Covid-19.

3. Bagi Desa Adat Kapal

Dalam keadaan pandemi Covid-19 diharapkan kepada umat Hindu di Desa Adat Kapal pada khususnya dapat mempertahankan serta melestarikan tradisi Tabuh Rah Pengangon yang sudah ada sejak jaman dahulu, namun tetap dengan mematuhi anjuran protokol kesehatan yang dianjurkan oleh pemerintah. 


\section{DAFTAR PUSTAKA}

Muslih Basthomi 2020. Urgensi Komunikasi Dalam menumbuhkan Motivasi di Pandemi Covid-19.

Budyatna, Muhammad dan Ganiem, Leila Mona. 2012. Teori Komunikasi Antarpribadi. Jakarta : Kencana Prenada Media Group.

Bungin, Burhan. 2011. Sosiologi Komunikasi. Jakarta : Kencana Prenada Media Group.

Cangara, Hafied. 2010. Pengantar Ilmu Komunikasi. Jakarta: Rajawali Pers.

Craib,1986.Teori Sosiologi Modern. Jakarta: PT Raja GravindoPersada.

Evi Zahara. 2018. Peranan Komunikasi Organisasi Bagi Pinpinan Organisasi.

Hamidi. 2004 Metode Penelitian Kualitatif (Aplikasi Praktis Pembuatan Proposal dan Laporan Penelitian) UMM Press: Malang.http://kabarwashliyah.com/2013/ 06/30/elit-lokal-bangun-daerah-harusmaksimal.

Widyantara, I Gede Suka (2020) Peranan Bendesa dalam Penyelesaian Sengketa Tanah Waris di Desa Adat Buduk.

I Gusti Ngurah Sudiana, Wayan P Windia, Relin DE. 2016. Prajuru Desa Pekraman Rohaniawan Hindu Dan Hukum, Denpasar: Bali Santi Pusat Pelayanan.

Ida Bagus Yudha Triguna, 2000. Teori Tentang Simbul, Denpasar: Widya Dharma.

Koentjaraningrat, 1990. Pengantar Ilmu Antropologi. Jakarta: Rineka Cipta.

M. N. Nasution, 2004. Manajemen Jasa

Terpadu, Bogor Ghalia Indonesia. Moleong, Mark dan goodson., 2003.

Metodologi Penelitian Kualitatif . Bandung : Remaja Rosdakarya.

Mulyana, Deddy, 2008. Komunikasi Massa. Bandung : Widya Padjadjaran.

Poerwadarminta. W.J.S. 1987. Kamus

Umum Bahasa Indonesia. Jakarta: Pusat Pembinaan dan Pengembangan Bahasa Departemen Pendidikan dan Kebudayaan.

Poloma,M.Margaret, 2003 Sosiologi Kontemporer, Jakarta: Kencana.Pudja, dkk. 1977. Dalam bahasa sansekerta metode dalam pramana . Jakarta: Lembaga Penerjemah Kitab Suci Weda.
Pratiwi, C. A. (2017). Harai: Telaah Konsep Religi Koentjaraningrat. Japanology, 173185.

Puja I Gede, 1982. Siwa Sesana, Jakarta: Proyek Pengaduan Kitab Hindu Departemen Agama. Puja, G.

1997. Sarasamuscaya. Surabaya: Paramita.

Puloma, Margaret M., 2003. Sosiologi Kontemporer. Jakarta : Raja Grafin

Riswadi, 2009. Pengantar Komunikasi.

Yogyakarta: Graha Ilmu. Singarimbun,

Efendi, 1995. Metode Penelitian Survey, Jakarta: PT Pustaka LP3ES.

Suasthawa Dharmayuda, I Made. 2001.Desa Adat (Kesatuan Masyarakat Hukum Adat di Propinsi Bali). Denpasar : Upada Sastra.

Sudirsa, I Komang, 2008. Dampak Tajen Terhadap Kehidupan Keluarga Bebotoh ditinjau dari Ajaran Etika Hindu di Desa Adat Pasedahan, Kecamatan Manggis, Kabupaten Karangasem. Denpasar : IHDN.

Sugiyono. 2016. Metode Penelitian Kuantitatif Kualitatif dan R\&D. Bandung: Alfabeta.

Suranto Aw, 2011 Komunikasi Interpesonal, Yogyakarta: Graha Ilmu.

Surat Edaran Guburnur Bali Nomor:

267/01-B/HK/2020. PembatasanSosial Berskala Besar.

Tabroni. 2001. Metodelogi Penelitian Sosial Agama. Bandung : PT Remaja Rosdakarya.

Wayan P.Windia2 (2017) Keberadaan Desa dan Adat Bali Serta Peranan

Bendesa Adat. E-Jurnal, Dosen Unud Bali.

Mahendra, Oka. 2001. Ajaran Agama Hindu Tentang Kepemimpinan, Konsep Negara dan Wiweka. Denpasar: Manikgeni.

Ruliana, Poppy. 2014. Komunikasi Organisasi: Teori dan Studi Kasus. Jakarta: Rajawali Pers.

Sudirga dkk, Ida Bagus. 2004. Widya Dharma Agama Hindu 1, 2 dan 3. Bandung: Ganeca.

Siagian, Sondong. P. 2003. Teori dan Praktek kepemimpinan, Jakarta: PT Rineka Cipta.

Sudarta, W. 2008. Penerapan Tri Hita

Karana di Subak Kawasan Perkotaan (Kasus Subak Anggabaya, Kota Denpasar). Denpasar: Jurnal SOCA, Vol. 9, No.2, Juli 2012 Fakultas PE Unud.

Surpha, Wayan. 1993. Eksistensi Desa Adat di Bali. Denpasar: PT. Upada Sastra. 
WHO. (2021, juni 13). WHO Coronavirus (COVID-19) Dashboard. Retrieved from WHO Coronavirus (COVID-19)

Dashboard: https://covid19.who.int/

Widjaja, A.W. 2000. Ilmu Komunikasi Pengantar

Studi. Jakarta: Rineka Cipta 